\title{
Impacts of whey protein on starch digestion in rumen and small intestine of steers
}

\author{
Sang-Bum Lee ${ }^{1}$, Kyoung-Won Lee ${ }^{2}$, Jae-Sung Lee ${ }^{1,3}$, Kyung-Hoon Kim ${ }^{4}$ and Hong-Gu Lee ${ }^{1,3^{*}}$ \\ 'Department of Animal Science and Technology, Sanghuh College of Life Sciences, Konkuk University, Seoul 05029, Korea \\ ${ }^{2}$ Life Science Technology Inc., Seoul 05029, Korea \\ ${ }^{3}$ Team of An Educational Program for Specialists in Global Animal Science, Brain Korea 21 Plus Project, Konkuk University, Seoul 05029, \\ Korea \\ ${ }^{4}$ Institute of Green Bio Science and Technology, Seoul National University, Pyeongchang 25354, Korea
}

\section{Abstract}

Four Korean native steers ( $511 \pm 17.2 \mathrm{~kg} ; 2 \times 2$ replicated crossover design) fitted with duodenal cannulas were used to investigate the influence of oral administration of soluble whey protein (WP; $82.29 \%$ crude protein) on ruminal fermentation, gastrointestinal $(\mathrm{GI})$ hormone secretion in the blood, pancreatic $\alpha$-amylase activity in the duodenum, and disappearance rate in each segment of the GI tract. Steers were orally fed the basal diet (control; TMR [total mixed ration] $9 \mathrm{~kg} / \mathrm{d}$ ) or the basal diet with enriched WP $(400 \mathrm{~g} / \mathrm{d})$ for 14 days. The apparent crude protein disappearance rate in the rumen of the WP was higher than in control $(p<0.05)$. However, no difference between groups was observed in the apparent crude protein disappearance rate in the intestine and the apparent starch disappearance rates in the rumen, GI tract. The level of cholecystokinin, secretin, and ghrelin in serum and pancreatic $\alpha$-amylase activity in the duodenum of the WP also did not change. The changes in the level of blood urea nitrogen related to protein metabolism were higher in the WP than in the control $(p<0.05)$. However, the levels of total protein, lipid, carbohydrate and mineral metabolites did not change. Consequently, we suggest that the oral administration of WP in steers assisted in ruminal fermentation due to the population increase of microbes in the rumen but did not improve the starch digestion rate in the small intestine because $\mathrm{Gl}$ hormone secretion in the blood and pancreatic $\alpha$-amylase activity did not change.

Keywords: Intestine, Korean native steer, Rumen fermentation, Starch disappearance rate, Whey protein

\section{Background}

Ruminants can digest high amounts of starch. However, since most feed contains over $60 \%$ starch, it is inevitable that some of the starch in feed will remain undigested [1]. In general, ruminants digest $78 \%$ to $90 \%$ of their starch intake [2]. On average, $35 \%$ to $60 \%$ of the starch entering the small intestine is decomposed, but $35 \%$ to $50 \%$ of the digestive food exiting the small intestine is digested in the large intestine [2]. However, the digestion rate of the large intestine is low, and the digested food is only related to survival of microbes in the large intestine, but is known to have a low relationship with the starch utilization of ruminants [1]. Thus, the digestion rate of the small intestine should be maximized to increase the utilization. In general, since the digestion process of ruminants is very complex, and many methods of increasing the production efficiency through starch are still available, we feel it necessary to accurately predict the digestion process of the small intestine and establish the most efficient method of starch diges-

Received: Feb 8,2019 Accepted: Mar 20,2019

"Corresponding author: Hong-Gu Lee, Department of Animal Science and Technology, Sanghuh College of Life Sciences, Konkuk University, Seoul 05029, Korea.

Tel: +82-2-450-0523, E-mail: hglee66@konkuk.ac.kr

This is an Open Access article distributed under the terms of the Creative Commons Attribution Non-Commercial License (http://creativecommons.org/licenses/by$\mathrm{nc} / 4.0 /$ ) which permits unrestricted non-commercial use, distribution, and reproduction in any medium, provided the original work is properly cited.

Copyright (C) 2019 Korean Society of Animal Science and Technology. 
tion.

Taniguchi et al. [3] proposed that it is possible to improve the starch digestion in the small intestine of ruminants by means of protein. Richard et al. [4] reported that the starch digestion rate in the small intestine of steers together with four stomachs is increased by the injection of casein. This finding proves that in particular, the control by soluble proteins affects the secretion and activity of $\alpha$-amylase in the small intestine, ultimately affecting the starch digestion.

Whey protein (WP) is a byproduct of the manufacturing process of cheese with a high content of soluble lactose (37\% to $72 \%$ ) $[5,6]$. WP can increase the entities of protozoa, which increases the utilization of carbohydrates in ruminant feeds [7-9]. These protozoa indirectly improve the decomposition of significant amounts of fiber in the feed [10-12] and increases the rumen fermentation and the microbial synthesis of protein [13]. According to earlier study, WP increases the concentration of butyric acid and milk fat precursors which ferment carbohydrate in the rumen of milk cows [14]. The addition of WP to feed based on grain and grass [15] or low-quality hay [6] was reported to increase the weight and organic intake of beef calves. In the paper by Miron et al. [16], it was claimed that this is because the inflow of WP with ample lactose into the rumen increases the creation of bacteria and protozoa which use WP as an energy source, helping decompose the cell wall with a high ratio of structural carbohydrate. In addition, WP can change the kind, activity, or environment of microbes [6].

However, the previous research conducted on the utilization of WP has mostly focused on the characteristics of rumen fermentation. Thus far, there have been few papers related to the starch digestion in the small intestine after the rumen. Therefore, the objective of this research on Korean native steers is to investigate the effect of the oral administration of WP, a soluble protein, on the ruminal fermentation and in-blood secretion of gastrointestinal (GI) hormones, which are related to starch digestion in the small intestine, and the activity of pancreatic $\alpha$-amylase in the small intestine, and then confirm the relationship of starch digestion in the small intestine.

\section{Materials and Methods}

\section{Animals and diet}

This research used four Korean native steers (average posted weight $511 \pm 17.2 \mathrm{~kg}$ ) fitted with rumen and duodenal cannulas. Under general local anesthesia, these animals were surgically fitted with cannulas at the rumen (Bar Diamond ${ }^{\mathrm{TM}}$, Inc., Parma, Idaho, USA) and the duodenum (Simple T shaped type; Bar Diamond ${ }^{\mathrm{TM}}$, Inc., USA) so that the digestive food and the duodenal fluid could be collected from the rumen and the duodenum. The specimen ani- mals were individually experimented on in the cattle shed with a fence of $3.0 \times 3.2 \mathrm{~m}$ and a concrete floor where temperature and light are controlled (at $23^{\circ} \mathrm{C}$, lights on for $16 \mathrm{~h}$, lights out for $8 \mathrm{~h}$ ), and water and a small amount of salt block were provided freely for the entire period. The weight of each animal was measured prior to the treatment period, and TMR $(9 \mathrm{~kg} / \mathrm{d})$ was supplied as a basal feed twice a day at 9:00 AM and 5:30 PM. For the intake of metabolic energy, 1.2 times the maintenance requirement for a Korean native steer [17] was supplied, and as a marker for measurement of the content of digestive food, chromium oxide $\left(\mathrm{Cr}_{2} \mathrm{O}_{3}\right)$ was added in the amount of $0.2 \%$ to the concentrated feed. The feed used in this research was WP (100\% Any WP, optimum nutrition, USA) composed of $100 \%$ protein (protein: $\geq 85.7 \%$; ash: $\leq 2.1 \%$; moisture: $\leq 1.9 \%$ ). The chemical compositions of WP and TMR used are given in Table 1. The study was authorized and undertaken in accordance with the ethics requirements of the Official Ethical Committee of Pusan National University (PNU 2015-0065).

Table 1. Ingredient and chemical composition of TMR and whey protein (WP)

\begin{tabular}{|c|c|c|}
\hline Item & TMR & WP \\
\hline \multicolumn{3}{|c|}{ Ingredient ( $\%$, of DM basis) } \\
\hline Corn (coarse cracked) & 38.20 & \\
\hline Wheat bran & 2.22 & \\
\hline Corn gluten feed & 7.94 & \\
\hline Soybean hull & 10.00 & \\
\hline Molasses & 5.00 & \\
\hline Whole cottonseed & 3.00 & \\
\hline Mushroom media & 8.00 & \\
\hline Fermentation feed & 6.00 & \\
\hline Rice straw (fresh) & 17.70 & \\
\hline Sodium bicarbonate & 0.50 & \\
\hline Limestone & 0.89 & \\
\hline Salt & 0.25 & \\
\hline Vitamin premix ${ }^{1)}$ & 0.30 & \\
\hline Total & 100.00 & \\
\hline \multicolumn{3}{|c|}{ Chemical composition (\%, of DM) } \\
\hline Moisture & 6.40 & 5.30 \\
\hline Starch & 30.90 & - \\
\hline $\mathrm{CP}$ & 11.60 & 87.40 \\
\hline Ash & 8.00 & 2.90 \\
\hline EE & 4.38 & 0.72 \\
\hline $\mathrm{CF}$ & 13.48 & 0.24 \\
\hline $\mathrm{Ca}$ & - & 0.44 \\
\hline$P$ & - & 0.20 \\
\hline \multicolumn{3}{|c|}{$\begin{array}{l}\text { Grobig DC provided following nutrients per kg of diet: 2,650,000 IU of vitamin A, } \\
530,000 \mathrm{IU} \text { of vitamin } \mathrm{D}_{3}, 1,050 \mathrm{IU} \text { of vitamin } \mathrm{E}, 10,000 \mathrm{mg} \text { of nicotinic acid, } 13,200 \mathrm{mg} \\
\text { of } \mathrm{Fe}, 4,400 \mathrm{mg} \text { of } \mathrm{Mn}, 4,400 \mathrm{mg} \text { of } \mathrm{Zn}, 2,200 \mathrm{mg} \text { of copper, } 440 \mathrm{mg} \text { of iodine, } 440 \\
\mathrm{mg} \text { of cobalt. TMR, total mixed ration; DM, dry matter; CP, crude protein; EE, ether } \\
\text { extract; CF, crude fiber; Ca, calcium; P, phosphorus. }\end{array}$} \\
\hline
\end{tabular}




\section{Experimentation design and treatment}

The beef steers were arranged randomly as the treatment group under the $2 \times 2$ replicated crossover method. For 11 days prior to the treatment, only the basal feed was supplied, to provide a feed adaptation period. After the adaptation, the steers fed a basal feed (control; TMR $9 \mathrm{~kg} / \mathrm{d}$ ) or the basal feed with WP (400 g/d) during the experimental periods. The WP group was treated for 14 days per period for 2-period experimentation. All the amounts in corporation of WP to TMR were set by converting the individual weight measured 1 day prior to each experimental period.

\section{Basal diet sampling}

Basal diet (500 g) was collected twice during each period, and then all the samples collected during the entire experimental period were mixed for application to the analysis. The samples were pulverized using a Wiley mill (Thomas Scientific Mode1 4, New Jersey, USA). Only the samples passed through the $1 \mathrm{~mm}$ net were used to analyze the moisture, crude protein, and ash using the general methods of AOAC [18], and starch was analyzed using the previous method [19].

\section{Serum sampling}

For analysis of GI hormones and metabolites, blood samples were collected at 8:30 (-30), 10:30 (90), 13:30 (270), and 16:30 (450) on day 14 , the last day of experimentation for each period. The $8: 30$ blood collection was conducted 30 mins prior to the morning feed supply. $20 \mathrm{~mL}$ of blood was collected from the jugular vein to pour $10 \mathrm{~mL}$ into each $10 \mathrm{~mL}$ serum tube (BD Vacutainer, BD, USA). In order to obtain serum at a refrigerated state of $4^{\circ} \mathrm{C}$ at the same time as the storage, centrifugal separation $(1,500 \times \mathrm{g}, 15 \mathrm{~min})$ was immediately performed. The upper layer liquid of serum was separated into $1.5 \mathrm{~mL}$ tubes for storage at $-80^{\circ} \mathrm{C}$ prior to the analysis.

\section{Sampling of duodenal fluids}

For analysis of the starch digestion rate of each GI tract, $250 \mathrm{~mL}$ of the contents which flow into the duodenum through duodenal cannula was collected at 8:30 (-30), 12:00 (180), 15:00 (360), at 18:00 (540) on day 12 during each period and 8:30 (-30), 10:30 (90), 13:30 (270), and at 16:30 (450) on day 13 during each period, was freeze-dried at $-20^{\circ} \mathrm{C}$ (Bodiro Programmable Freeze dryer, Ilshin Lab. Co., Ltd., Gyeonggi-do, Korea), and then was pulverized to $1 \mathrm{~mm}$ using the disc mill (Model BM-D 100, Disc mill, McCoy Corp., San Marcos, TX). After the pulverization, all samples collected regardless of the collection time for each period were mixed for analysis of DM, CP, Ash, Starch, and Cr.

For analysis of $\alpha$-amylase activity in the duodenal fluid, $50 \mathrm{~mL}$ of duodenal fluids was collected through the cannula installed at the duodenum at 8:30 (-30), 10:30 (90), 13:30 (270), and 16:30
(450) on day 14 of each period, and then frozen at $-80^{\circ} \mathrm{C}$ prior to the analysis.

\section{Sampling of rumen fluids}

For analysis of the starch digestion rate for each GI tract, 300 $\mathrm{mL}$ of rumen fluids was sampled at 8:30 (-30), 10:00 (60), 12:00 (180), and 14:00 (300) on day 14 of each period. Immediately after the sample collection, the contents were filtered through 4-layer gauze to remove large particles from the sample, and then $\mathrm{pH}$ was measured using the $\mathrm{pH}$ meter (SevenEasy ${ }^{\mathrm{TM}} \mathrm{pH}$ meters Mettler-Toledo AG 8603, Schwerzenbach, Switzerland). After $\mathrm{pH}$ measurement, they were pretreated with ammonia for analysis of volatile fatty acids (VFA), and then stored in frozen state $\left(-70^{\circ} \mathrm{C}\right)$ in a deep freezer prior to the analysis.

\section{Feces collection}

Feces (300 g) was sampled at the same time as duodenal fluids using the retro-vaginal technique. All the sampled feces were dried at $70^{\circ} \mathrm{C}$ in the hot air circulation dryer (Vision scientific Co. Ltd., Daejeon-si, South Korea) for over $72 \mathrm{hr}$, and then the weight was measured. After the dried samples were pulverized to $1 \mathrm{~mm}$ using the disc mill (Model BM-D 100, Disc mill, McCoy Corp., San Marcos, TX), all samples collected regardless of the collection time of each period were mixed to take a sample for analysis of DM, $\mathrm{CP}$, Ash, Starch, and Cr.

\section{Ruminal characteristics (VFA)}

The volatile fatty acid in the rumen was analyzed using the method of Erwin et al. [20], as follows: As the pretreatment process for measurement of VFA, $1 \mathrm{~mL}$ of rumen fluids was sampled to put it into a $1.5 \mathrm{~mL}$ micro tube, and then $0.01 \mathrm{~mL}$ of $\mathrm{HgCl}_{2}$ was added to stop the activity of microbes. After putting $0.2 \mathrm{~mL}$ of $\mathrm{H}_{3} \mathrm{PO}_{4}$ into the mixed fluid in order to remove the microbial protein, 0.04 $\mathrm{mL}$ of pivalic acid, the internal standard for analysis of Gas chromatography (GC), was added. Then, the mixed fluid was stored in a frozen state $\left(-70^{\circ} \mathrm{C}\right)$ in a deep freezer until the analysis. Next, the sample was melted at room temperature for the centrifugal separation at 5,300 $\times \mathrm{g}$ for $5 \mathrm{~min}$. The upper layer fluid was taken for analysis with GC (VARIAN model CP-3800, CA, USA). VFA standard solution was prepared as follows: After massing $100 \mathrm{~mL}$ of distilled water, $0.35 \mathrm{~mL}$ of acetate, $0.15 \mathrm{~mL}$ of propionate, 0.05 $\mathrm{mL}$ of isobutyrate, $0.1 \mathrm{~mL}$ of butyrate, $0.05 \mathrm{~mL}$ of isovalerate, 0.05 $\mathrm{mL}$ of valerate, and $5 \mathrm{~mL}$ of standard solution containing $0.2 \mathrm{~mL}$ of pivalic acid were added. $1 \mathrm{~mL}$ of the mixed solution was taken into a GC vial for use as VFA standard. The content of VFA in samples was measured in comparison with the calibration curve of VFA standard solution. 
Immunoassay methods of GI hormone secretion in steer serum

The serum concentration of ghrelin, secretin, and cholecystokinin (CCK)-8 was measured using such enzyme immunoassay methods as ghrelin (EK-031-30), secretin (EK-067-05), and CCK-8 (EK069-04; Phoenix Pharmaceuticals Inc., USA) using a secondary antibody-coated plate. The immunoassay of ghrelin, secretin and CCK-8 in steer serum was performed in the same manner as in our previous research [21-23].

\section{Analysis of $\alpha$-amylase activity in duodenal fluid of exo-} crine pancreas

The $\alpha$-amylase activity of the duodenal fluid secreted from the exocrine pancreas was measured by using EnzyChrom ${ }^{\mathrm{TM}} \alpha$-amylase Assay Kit (ECAM-100, BioAssay Systems, CA, USA).

\section{Analysis of starch digestion rate in GI fluids}

The analysis of the nutrient digestion rate for each GI tract was performed using the anthrone method [24], which develops color with anthrone by using $\mathrm{D}$-glucose as a standard reagent, and the analytical method of McCready et al. [19]. To describe it briefly, the GI fluid stored in a frozen state was melted at room temperature, and then pulverized below $0.5 \mathrm{~mm}$ under ice using a homogenizer. After the pulverization, the fluid was filtered using 2-layers of gauze (below- $0.5 \mathrm{~mm}$ sieve), and $0.2 \mathrm{~g}$ of the sample was put into a $50-\mathrm{mL}$ falcon tube (error allowance: $0.2 \pm 0.001 \mathrm{~g}$ ). To the sample of $0.2 \mathrm{~g}, 2$ to 3 drops of $80 \%$ ethanol were added to wet the sample, and then $5 \mathrm{~mL}$ of distilled water was added. $25 \mathrm{~mL}$ of $80 \%$ ethanol stored at $75^{\circ} \mathrm{C}$ was added to the sample, followed by mixing. After it was left for $5 \mathrm{~min}$, the sample was centrifuged at $980 \times \mathrm{g}$ for $10 \mathrm{~min}\left(1^{\text {st }}\right.$ centrifugal separation). After the centrifugal separation, the supernatant solution was discarded, and $30 \mathrm{~mL}$ of $80 \%$ ethanol at $75^{\circ} \mathrm{C}$ was added to the sample. After the wellmixed solution was left for $5 \mathrm{~min}$, another centrifugal separation was conducted at $980 \times \mathrm{g}$ for $10 \mathrm{~min}$ ( $2^{\text {nd }}$ centrifugal separation). $1 \mathrm{~mL}$ of the supernatant solution was taken to develop color in 5 $\mathrm{mL}$ of anthrone solution (solution prepared by dissolving $0.1 \mathrm{~g}$ of anthrone into $100 \mathrm{~mL}$ of the sulfuric acid solution, which is prepared by adding distilled water to $760 \mathrm{~mL}$ of sulfuric acid until the total solution reaches $1 \mathrm{~L}$ ) and confirm whether or not a blue color is observed. At this time, if the blue color is developed, the centrifugal separation continues until the color disappears. After the centrifugal separation, the upper layer solution was discarded, and the residue was dried $\left(40^{\circ} \mathrm{C}\right.$ to $\left.50^{\circ} \mathrm{C}, 60 \mathrm{~min}\right)$. The residue should be dried enough to remove the ethanol component completely. The temperature should not go over $60^{\circ} \mathrm{C}$ so as not to denature glucose and protein. After the drying, $5 \mathrm{~mL}$ of distilled water was added. To the mixture, $6.5 \mathrm{~mL}$ of $52 \%$ perchloric acid reagent was added every $5 \mathrm{~min}$, for a total of $20 \mathrm{~min}$. After the total mixture was mixed with $20 \mathrm{~mL}$ of distilled water, centrifugal separation was performed $(980 \times \mathrm{g}, 10 \mathrm{~min})$. After the centrifugal separation, $100 \mathrm{~mL}$ of the upper layer solution was filtered into a $100 \mathrm{~mL}$ volumetric flask. The processes after the drying were repeated once again. The residue of the leftover sample was filtered with distilled water to fill the flask exactly up to $100 \mathrm{~mL}$ (the last pretreatment process of sample). $1 \mathrm{~mL}$ of such standard solutions as $2.5 \mathrm{~mL}$ (25 $\mu \mathrm{g} / \mathrm{mL}), 5 \mathrm{~mL}(50 \mu \mathrm{g} / \mathrm{mL}), 10 \mathrm{~mL}(100 \mu \mathrm{g} / \mathrm{mL}), 15 \mathrm{~mL}(150 \mu \mathrm{g} /$ $\mathrm{mL})$, and $20 \mathrm{~mL}(200 \mu \mathrm{g} / \mathrm{mL}) / 100 \mathrm{~mL}$-distilled water and $1 \mathrm{~mL}$ of sample solution were put into a $20-\mathrm{mL}$ tube, and then $5 \mathrm{~mL}$ of anthrone reagent was added. The process of color development was conducted at $100{ }^{\circ} \mathrm{C}$ for 12 to $13 \mathrm{~min}$. After the color development, the sample was quenched to room temperature, and the measurements were made with the spectrophotometer $(630 \mathrm{~nm})$. Prior to the measurement of all the samples, any one of them was diluted stepwise, and then compared with the standard solution to select the dilution ratio, which was then applied to all samples for analysis. The starch digestion rate was calculated by obtaining the D-glucose content in each digestive organ and then comparing it with $\mathrm{Cr}$ content. The $\mathrm{D}$-glucose content of the feed was converted to the starch content.

\section{Chromium oxide $\left(\mathrm{Cr}_{2} \mathrm{O}_{3}\right)$}

A sample $(2 \mathrm{~g})$ was put into a porcelain crucible, 0.5 to $1 \mathrm{~mL}$ of No. 3 potassium phosphate solution $\left(\mathrm{K}_{3} \mathrm{PO}_{4}\right)$, a chromium oxidant, was added to the sample depending on the state of the sample, and then the sample and the solution were mixed completely by stirring with a glass rod. The glass rod was washed with cotton wool, put into the porcelain crucible to pre-incinerate them together with the sample in the electric furnace (Muffle furnace, Model MF64, HYSC, Seoul, South Korea), and then burned at $800^{\circ} \mathrm{C}$ for 50 min. After cooling to room temperature, the contents left in the crucible were eluted with distilled water into a $100-\mathrm{mL}$ volumetric flask until the mixture reaches the mark line. Then, the mixture was left for $24 \mathrm{hr}$. Thereafter, the sample was filtered to measure chromium concentration with inductively coupled plasma.

\section{Calculation of nutrient digestion rate for each GI organ}

The daily amount of the flowed nutrient (flow, g/d) for the daily amount of supplied chromium was obtained using the ratio of chromium to the amount of the nutrient in the contents of the samples collected from GI tract. The equation is as follows.

$$
\begin{aligned}
& \text { gDM flow/d at sample collection site }= \\
& \qquad \frac{\text { Marker input }(g / d)}{\text { Marker concentration in sample }(g / g D M)}
\end{aligned}
$$


By substituting the amount of flow into the small intestine and amount of discharge into feces as obtained by the above equation into the equations below, the amount of nutrient digestion (Disappearance, g/d) and rate of nutrient digestion (Disappearance, \%) for the rumen, lower digestion tubes, and each GI tract were obtained.

- Whole stomach disappearance = Intake - Duodenal flow

- Intestine disappearance $=$ Duodenal flow - Fecal flow

- Total tract disappearance $=$ Whole stomach disappearance + Intestine disappearance

\section{Analysis of metabolites in serum}

The analysis of metabolites in blood was performed using Toshiba Acute Biochemical Analyzer-TBA-40FR (Toshiba Medical Instruments, Tochigi-ken, Japan), a biochemical analyzer, to confirm in the serum if the biological metabolic index is changed in comparison with the control group.

\section{Statistical analysis}

The analysis of variance (ANOVA) used SPSS 14.0K (SPSS, Chicago, IL, USA) for window, and the significance of the difference between the control group and the WP group was verified using the student $t$-test when ANOVA declared significant difference at $p<0.05$.

\section{Results}

\section{Rumen fermentation characteristics}

The rumen fermentation characteristics due to the addition of WP to the basal feed are given in Table 2. No significant difference between the groups in the $\mathrm{pH}$ of the rumen was observed $(p>0.05)$. In addition, there was no difference shown in total VFA, or in acetate, propionate, butyrate, and acetate/propionate ratio out of VFA $(p>0.05)$. However, the ratios of valerate and isovalerate out of VFA increased significantly in the WP group in comparison with the control group $(p<0.05)$.

\section{Flow and digestion rate for each area of GI tract}

The flow and digestion rate of crude protein for each area of the GI tract due to the addition of WP to the basal feed are given in Table 3. As shown in the Table, the crude protein intake of the WP group $(1,304.1 \mathrm{~g} / \mathrm{d})$ was higher than that of the control group $(973.1 \mathrm{~g} / \mathrm{d})(p<0.05)$. However, the content of crude protein flowing into the small intestine showed only a difference of $94 \mathrm{~g} / \mathrm{d}$ between the control group $(485.1 \mathrm{~g} / \mathrm{d})$ and the WP group $(579.1 \mathrm{~g} / \mathrm{d})$, which was insignificant $(p>0.05)$. The content of crude protein for discharge into feces also did not show a large difference between
Table 2. Ruminal characteristics in beef steers fed TMR and whey protein (WP)

\begin{tabular}{|c|c|c|c|c|}
\hline \multirow{2}{*}{ Item } & \multicolumn{2}{|c|}{ Treatment $^{1)}$} & \multirow{2}{*}{ SEM $^{2}$} & \multirow{2}{*}{$p$-value ${ }^{3)}$} \\
\hline & Control & WP & & \\
\hline $\mathrm{pH}$ & 6.52 & 6.47 & 0.05 & 0.596 \\
\hline Total VFA (mmol) & 80.58 & 91.29 & 11.22 & 0.222 \\
\hline \multicolumn{5}{|l|}{ VFA concentration } \\
\hline Acetate (mmol) & 63.72 & 59.03 & 1.35 & 0.152 \\
\hline Propionate (mmol) & 21.25 & 23.41 & 1.05 & 0.294 \\
\hline Butyrate (mmol) & 13.07 & 12.60 & 0.53 & 0.674 \\
\hline Valerate (mmol) & $1.28^{\mathrm{a}}$ & $1.68^{\mathrm{b}}$ & 0.09 & 0.004 \\
\hline Isovalerate (mmol) & $1.92^{\mathrm{a}}$ & $3.29^{b}$ & 0.28 & 0.004 \\
\hline Acetate : propionate & 3.03 & 2.57 & 0.17 & 0.170 \\
\hline
\end{tabular}

${ }^{11} \mathrm{Control}$, TMR $9 \mathrm{~kg} / \mathrm{d}$; WP, control with whey protein $400 \mathrm{~g} / \mathrm{d}$.

${ }^{2)}$ Standard error of mean.

${ }^{3)} p$-values were calculated by paired $t$-test.

${ }^{a, b}$ Means in each row with different superscripts are significantly different $(p<0.05)$.

TMR, total mixed ration; VFA, volatile fatty acids.

Table 3. Apparent crude protein (CP) disappearance rates in each segment of gastrointestinal tract in beef steers TMR and whey protein (WP)

\begin{tabular}{lcccc}
\hline \multirow{2}{*}{ Item } & \multicolumn{2}{c}{ Treatment $^{\text {1) }}$} & \multirow{2}{*}{ SEM $^{2)}$} & $\boldsymbol{p}^{\text {p-value }}{ }^{3)}$ \\
\cline { 2 - 3 } & Control & WP & & \\
\hline CP intake (g/d) & $973.1^{\mathrm{a}}$ & $1,304.1^{\mathrm{b}}$ & 74.01 & $<.0001$ \\
Duodenal flow (g/d) & 485.1 & 579.1 & 25.59 & 0.170 \\
Fecal flow (g/d) & 150.8 & 166.3 & 11.27 & 0.337 \\
Disappearance (g/d) & & & & \\
$\quad$ Rumen & $488.0^{\mathrm{a}}$ & $725.1^{\mathrm{b}}$ & 54.97 & 0.022 \\
Intestine & 334.2 & 412.8 & 21.73 & 0.153 \\
$\quad$ Total tract & $822.3^{\mathrm{a}}$ & $1,137.8^{\mathrm{b}}$ & 71.36 & 0.001 \\
Disappearance (\%) & & & & \\
$\quad$ Rumen, of intake & 50.2 & 55.6 & 1.92 & 0.223 \\
Intestine, of flow & 69.0 & 71.2 & 1.78 & 0.126 \\
Total tract, of intake & $84.5^{\mathrm{a}}$ & $87.2^{\mathrm{b}}$ & 1.22 & 0.033 \\
\hline
\end{tabular}

${ }^{1)} \mathrm{Control}$, TMR $9 \mathrm{~kg} / \mathrm{d}$; WP, control with whey protein $400 \mathrm{~g} / \mathrm{d}$.

${ }^{2}$ Standard error of mean.

${ }^{3)} p$-values were calculated by paired $t$-test.

a,b Means in each row with different superscripts are significantly different $(p<0.05)$. TMR, total mixed ration.

the control group $(150.8 \mathrm{~g} / \mathrm{d})$ and the WP group $(166.3 \mathrm{~g} / \mathrm{d})$. The amount of protein digestion in the rumen of the WP group (725.1 $\mathrm{g} / \mathrm{d})$ was higher than that of the control group $(488.0 \mathrm{~g} / \mathrm{d})(p<0.05)$. In the small intestine, however, the WP group $(412.8 \mathrm{~g} / \mathrm{d})$ digested $78.6 \mathrm{~g} / \mathrm{d}$ more than the control group $(334.2 \mathrm{~g} / \mathrm{d})$, which is not significant $(p>0.05)$. Consequently, the crude protein digestion of the entire GI tract was higher to a statistically significant level in the rumen of WP group $(p<0.05)$. 
Flow and digestion rate of starch for each area of the $\mathrm{GI}$ tract

The flow and digestion rate of starch for each area of the GI tract due to addition of WP to the basal feed are given in Table 4. The results showed no difference between the starch content for flow

Table 4. Apparent starch disappearance rates in each segment of gastrointestinal tract in beef steers fed TMR and whey protein (WP)

\begin{tabular}{lrrrc}
\hline \multirow{2}{*}{ Item } & \multicolumn{2}{c}{ Treatment $^{1)}$} & \multirow{2}{*}{ SEM $^{2)}$} & p-value $^{3)}$ \\
\cline { 2 - 3 } & Control & \multicolumn{1}{c}{ WP } & & \\
\hline Starch intake (g/d) & $2,666.5$ & $2,666.5$ & 0 & - \\
Duodenal flow (g/d) & 843.7 & 704.4 & 57.34 & 0.353 \\
Fecal flow (g/d) & 152.8 & 105.6 & 23.77 & 0.094 \\
Disappearance (g/d) & & & & \\
$\quad$ Rumen & $1,822.8$ & $1,962.1$ & 57.34 & 0.353 \\
$\quad$ Intestine & 690.9 & 598.9 & 65.23 & 0.654 \\
$\quad$ Total tract & $2,513.7$ & $2,560.9$ & 23.77 & 0.094 \\
Disappearance (\%) & & & & \\
$\quad$ Rumen, of intake & 68.4 & 73.6 & 2.15 & 0.353 \\
$\quad$ Intestine, of flow & 81.0 & 84.5 & 3.48 & 0.333 \\
Total tract, of intake & 94.3 & 96.0 & 0.89 & 0.094 \\
\hline
\end{tabular}

${ }^{1)} \mathrm{Control}$, TMR $9 \mathrm{~kg} / \mathrm{d}$; WP, control with whey protein $400 \mathrm{~g} / \mathrm{d}$.

${ }^{2)}$ Standard error of mean

${ }^{3)} p$-values were calculated by paired $t$-test.

TMR, total mixed ration. into the small intestine and the starch content in feces, and the digestion rate also showed no difference between the rumen and the duodenum $(p>0.05)$. However, the starch content flowing into the small intestine was $139.3 \mathrm{~g} / \mathrm{d}$ more in the rumen of the WP group $(704.4 \mathrm{~g} / \mathrm{d})$ than the control group $(843.7 \mathrm{~g} / \mathrm{d})$. And amount of digestion $(139.3 \mathrm{~g} / \mathrm{d})$ and the digestion rate $(5.2 \%)$ also showed more increased values in the rumen of the WP group than the control group. However, the starch content in feces showed a difference of $47.2 \mathrm{~g} / \mathrm{d}$ between the control group $(152.8 \mathrm{~g} / \mathrm{d})$ and the WP group $(105.6 \mathrm{~g} / \mathrm{d})$, which was smaller than that in the rumen, indicating that the starch utilization in the small intestine was significantly decreased by the addition of WP to basal feed in beef steers. This could be supported by the amounts of digestion in the small intestine of the control group $(690.9 \mathrm{~g} / \mathrm{d})$ and the WP group $(598.9 \mathrm{~g} / \mathrm{d})$. However, there was no significant difference $(p>0.05)$.

\section{Relationship between GI hormone and $\alpha$-amylase activ-} ity of pancreatic external-secretion duodenal fluid due to WP treatment

The relationship between GI hormone and $\alpha$-amylase activity due to addition of WP to the basal feed are shown in Fig. 1 and Table 5. Overall, the addition of WP to the basal feed in this experiment showed no close relationship with ghrelin, CCK, and secretin, the GI hormones related to the secretion of enzymes, and the activity of $\alpha$-amylase, a starch decomposition enzyme $(p>0.05)$. For GI
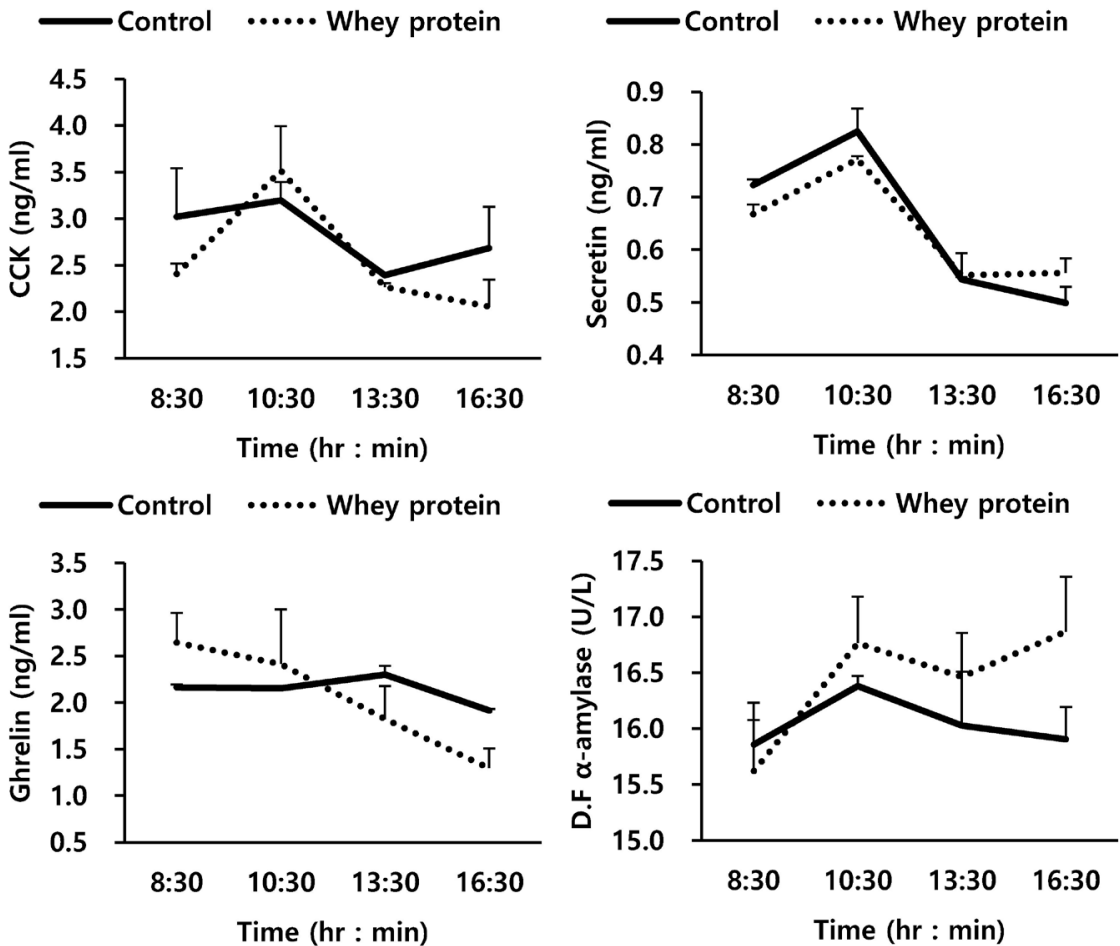

Fig. 1. Changes in levels of serum gastrointestinal hormones and duodenum $\alpha$-amylase in beef steers fed TMR without or with whey protein (WP). Vertical bars indicate standard error of mean. CCK, cholecystokinin; D.F a-amylase, duodenum fluid a-amylase. 
Table 5. Effects of oral administration of whey protein (WP) on serum ghrelin, cholecystokinin (CCK)-8, secretin and duodenum a-amylase concentration in beef steers

\begin{tabular}{|c|c|c|c|c|}
\hline \multirow{2}{*}{ Item } & \multicolumn{2}{|c|}{ Treatment ${ }^{1)}$} & \multirow{2}{*}{ SEM $^{2)}$} & \multirow{2}{*}{$p$-value ${ }^{3)}$} \\
\hline & Control & WP & & \\
\hline Ghrelin (ng/mL) & 2.161 & 2.044 & 0.58 & 0.331 \\
\hline $\mathrm{CCK}(\mathrm{ng} / \mathrm{mL})$ & 2.823 & 2.560 & 0.34 & 0.233 \\
\hline Secretin $(\mathrm{ng} / \mathrm{mL})$ & 0.648 & 0.637 & 0.09 & 0.342 \\
\hline D. F a-amylase ${ }^{4)}(\mathrm{U} / \mathrm{L})$ & 16.043 & 16.429 & 0.50 & 0.384 \\
\hline
\end{tabular}

${ }^{11}$ Control, TMR $9 \mathrm{~kg} / \mathrm{d}$; WP, control with whey protein $400 \mathrm{~g} / \mathrm{d}$.

${ }^{2)}$ Standard error of mean.

${ }^{3)} p$-values were calculated by paired $t$-test.

TMR, total mixed ration; CCK, cholecystokinin; D. F a-amylase, duodenum fluid $\alpha$-amylase.

hormones, the time change after the oral treatment also showed a similar trend to that of the control group, while for duodenal $\alpha$ -amylase activity, the WP group also did not show any significant difference from the control group $(p>0.05)$. In Table 5 , which shows the average values of the entire experimental period, it can be seen that the WP group also did not show any effects on GI hormones and pancreatic external secretion.

\section{Change of metabolites in blood due to treatment of WP}

Meanwhile, according to the results for investigation of the change of metabolites in blood due to addition of WP (Fig. 2), BUN (Blood Urea Nitrogen) out of the protein metabolites increased more significantly in the WP group than in the control group $(p$ $<0.01$ ), but no difference was observed between the control group and the WP group for the other protein metabolites (total protein, albumin), lipid metabolites (triglyceride, total cholesterol), carbohydrate metabolites (glucose), and mineral metabolites (phosphorus, magnesium, calcium).

\section{Discussion}

The addition of WP to the animal feed did not affect the change of $\mathrm{pH}$ and total VFA, the rumen fermentation characteristics, but the concentration of valerate and isovalerate out of VFA concentrations increased significantly in the WP group $(p<0.05$; Table 2). The increased supply of protein to ruminants was reported to increase branched-chain volatile fatty acids (BCVFA) $[25,26]$. According to the research findings of Ludden et al. [25] for different-level supply of CP content to sheep (0\%,13\%, 15\%, and 17\%), as $\mathrm{CP}$ content increased, the ratios of valerate and isovalerate increased significantly $(p<0.05)$. The research of Ipharraguerre et al. [26] also reported that as the supply of CP to milk cows increased, the ratios of isovalerate and isobutyrate increased significantly $(p<$ $0.05)$. In the rumen, BCVFA was reported to be created in the decomposition process of such branched-chain amino acids (BCAA) as valine, leucine, iso-leucine, and proline or used in re-synthesis of BCAA [27-29], and to increase the synthesis of rumen microbial protein and the digestion rate of structural carbohydrates and dried materials [30].

The results of the investigation of the flow and digestion rate of protein for each area of the GI tract due to the addition of WP to the basal feed (Table 3) show that while significantly more digestion was conducted in the rumen of the WP group than the control group $(p<0.05)$, no changes were observed in the small intestine $(p>0.05)$. Galloway et al. [6] proposed that WP could change the kind, activity, or environment of microbes. In ruminants, numerous studies have reported that WP promoted the creation of such microbes as bacteria and protozoa in the rumen [7-9], and increased the ruminal fermentation and the protein synthesis of microbes [13]. Since WP contains a lot of protein and lactose, the propagation of bacteria and protozoa, which use protein and lactose as an energy source, was reported to increase with the use of WP [16]. Eventually, the ruminal microbes propagated by the lactose contained in WP were confirmed to decrease the content of crude protein for flow into the small intestine by increasing the decomposition and utilization of WP crude protein.

The results of the investigation of the flow and digestion rate of starch for each area of GI tract due to the addition of WP to the basal feed (Table 4) also showed no difference in the starch content flowing into the small intestine, the starch content in feces, and the digestion rate between the rumen and the duodenum $(p$ $>0.05$ ), but showed that the use of starch in the entire GI tract tended to be increased by the addition of WP to the basal feed ( $p$ $=0.094)$. In addition, although there was no significant difference, the starch content flowing into the small intestine was used more in the rumen of the WP group $(704.4 \mathrm{~g} / \mathrm{d})$ than the control group $(843.7 \mathrm{~g} / \mathrm{d})$. Furthermore, the amount of digestion $(139.3 \mathrm{~g} / \mathrm{d})$ and the digestion rate (5.2\%) also showed more increased values in the rumen of the WP group than in the control group.

In general, the addition of WP to the basal feed of ruminants was reported to improve the decomposition of fiber in the rumen by increasing the population of ruminal protozoa [7-9], decreasing the amount of non-structural carbohydrates [6]. Additionally, this protozoa was reported to indirectly improve the decomposition of starch by assisting in decomposition of the cell wall of fiber with a high ratio of structural carbohydrates in the feed $[10-12,16]$. Thus, the addition of WP to the basal feed was confirmed to improve the starch decomposition in the rumen by assisting in the creation of ruminal microbes in the rumen, but had only a small influence on the starch digestion in the small intestine.

The results of the investigation of the relationship between GI hormones and $\alpha$-amylase activity due to the oral treatment of WP (Fig. 1 and Table 5) show that the oral treatment of WP, 

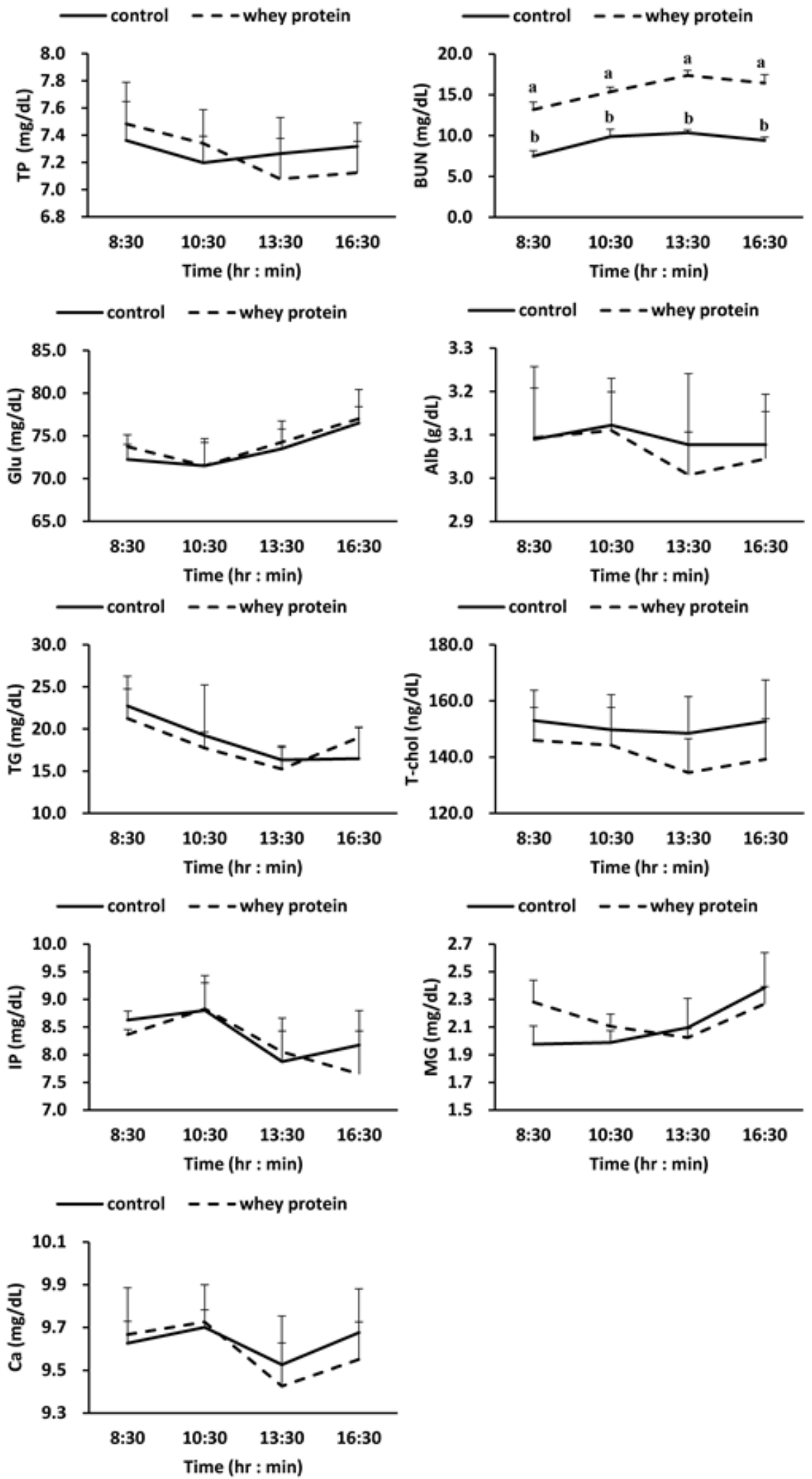

Fig. 2. Metabolic parameters in serum of beef steers fed whey protein (WP). ${ }^{\mathrm{a}, \mathrm{b}}$ Means in each row with different superscripts are significantly different $(p$ $<0.01$ ). Vertical bars indicate standard error of mean. TP, total protein; BUN, blood urea nitrogen; Glu, glucose; Alb, albumin; TG, triglycerides; T-chol, total cholesterol; IP, inorganic phosphate; MG, magnesium; Ca, calcium. 
overall, was not closely related to ghrelin, CCK, and secretin, the GI hormones related to the secretion of enzymes, or the activity of $\alpha$-amylase, an enzyme for decomposition of starch $(p<0.05)$. $\alpha$-Amylase is a starch decomposition enzyme secreted from the small intestine by stimulating the pancreatic cystocavitary cell with CCK and secretin, the GI hormones stimulated by amino acids / fatty acids flowed into the small intestine, and $\mathrm{pH}[31,32]$. In particular, according to the findings of previous research using intact casein (IC), such GI hormones as CCK and secretin were confirmed to be increased significantly by peptide and soluble non-ammonia $\mathrm{N}$ (SNAN) out of the proteins flowed into the small intestine [21]. The reason for the difference between IC and WP in the secretion of internal-secretion hormones and pancreatic $\alpha$-amylase may be due to a representative factor of the component difference between IC and WP. While IC is composed of $\alpha$-casein 59\% ( $\alpha$ S1-, $\alpha$ S2-), $\kappa$-casein 15\%, $\beta$-casein 38\%, and $\gamma$-casein 3\%,WP is composed of $\beta$-lactoglobulin 65\%, $\alpha$ -lactalbumin $25 \%$, bovine serum albumin $8 \%$, and immunoglobulins $2 \%$. In general, bacteria and protozoa which live in the rumen mentioned earlier use high amounts of the lactose of WP, which decreases the content of non-decomposed proteins (rumen undegradable protein, RUP) in the rumen. According to the paper by Bethard et al. [33], the supply of RUP to ruminants could improve the efficiency and growth of nitrogen utilization by increasing the content of amino acid and nitrogen $(\mathrm{N})$ flowed into the small intestine. Such GI hormones as CCK and secretin were reported to be affected by amino acid and nitrogen flowed into the small intestine, particularly SNAN [4,34], but the addition of WP to the feed could not affect the crude protein flowed into the small intestine (Table 3). In addition, WP may be used as an energy source of ruminal microbes (protozoa, bacteria) to increase the population of ruminal microbes in the rumen. It is judged that while the ruminal microbes increased the utilization of protein in the rumen, they could not affect the stimulation of internal-secretion hormones for protein flowed into the small intestine.

In this research, the addition of WP to the basal feed increased the concentration of BUN out of the blood metabolites (Fig. 2). From this phenomenon, it is judged that the amino acid created by the decomposition of protein from the WP was deaminated by various enzymes into ammonia, which was then synthesized into urea in the liver through the urea cycle [35]. However, the addition of WP to the basal feed did not affect such other protein metabolites as total protein and albumin, mineral metabolites, lipid metabolites, and carbohydrate metabolites.

Thus, we considered that though WP-added supply may assist in ruminal fermentation due to the population increase of microbes in the rumen, it does not affect the secretion of hormones related to the starch digestion in the small intestine and the secretion of $\alpha$-amylase in the pancreas, nor does it assist in starch digestion in the small intestine.

\section{Competing interests}

No potential conflict of interest relevant to this article was reported.

\section{Funding sources}

This work was supported by Cooperation Research Project (2017R1A2B2009752) funded by National Research Foundation of Korea.

\section{Acknowledgements}

Lee SB and Lee KW equally contributed to this study.

\section{Availability of data and material}

The data generated or analyzed during the current study are available from the corresponding author on reasonable request.

\section{Authors' contributions}

Conceptualization: Lee HG.

Data curation: Lee SB, Lee KW, Lee HG.

Formal analysis: Lee SB, Lee KW.

Methodology: Lee HG, Kim KH.

Software: Lee SB, Lee JS.

Validation: Kim KH, Lee HG.

Investigation: Lee SB, Lee KW.

Writing - original draft: Lee SB.

Writing - review \& editing: Lee SB, Lee JS, Lee HG.

\section{Ethics approval and consent to participate}

The study was authorized and undertaken in accordance with the ethics requirements of the Official Ethical Committee of Pusan National University (PNU 2015-0065).

\section{ORCID}

Sang-Bum Lee

Kyoung-Won Lee

Jae-Sung Lee

Kyung-Hoon Kim

Hong-Gu Lee

https://orcid.org/0000-0001-5761-8483

https://orcid.org/0000-0001-8019-1860

https://orcid.org/0000-0001-8940-9862

https://orcid.org/0000-0002-7288-7443

https://orcid.org/0000-0002-0679-5663

\section{References}

1. Harmon DL. Understanding starch utilization in the small intestine of cattle. Asian-Australas J Anim Sci. 2009;22:915-22.

2. Harmon DL, Taylor CC. Factors influencing assimilation of dietary starch in beef and dairy cattle. In: Proceedings of the Southwest Nutrition Conference; Nebraska. 2005. p. 55-66. 
3. Taniguchi K, Huntington GB, Glenn BP. Net nutrient flux by visceral tissues of beef steers given abomasal and ruminal infusions of casein and starch.J Anim Sci. 1995;73:236-49.

4. Richards CJ, Swanson KC, Paton SJ, Harmon DL, Huntington GB. Pancreatic exocrine secretion in steers infused postruminally with casein and cornstarch.J Anim Sci. 2003;81:1051-6.

5. Maiga HA, Schingoethe DJ, Ludens FC. Evaluation of diets containing supplemental fat with different sources of carbohydrates for lactating dairy cows.J Dairy Sci. 1995;78:1122-30.

6. Galloway DL Sr, Goetsch AL, Sun W, Forster LA Jr, Murphy GE, Grant EW, et al. Digestion, feed intake, and live weight gain by cattle consuming bermudagrass hay supplemented with whey.J Anim Sci. 1992;70:2533-41.

7. Mackie RI, Gilchrist FMC, Robberts AM, Hannah PE, Schwartz HM. Microbiological and chemical changes in the rumen during the stepwise adaptation of sheep to high concentrate diets.J Agric Sci (Camb.). 1978;90:241-54.

8. Chamberlain DG, Thomas PC, Wilson W, Newbold CJ, MacDonald JC. The effects of carbohydrate supplements on ruminal concentrations of ammonia in animals given diets of grass silage.J Agric Sci (Camb.). 1985;104:331-40.

9. Kudo H, Cheng KJ, Imai S, Han SS, Costerton JW. Effects of feed on the composition of the rumen ciliate protozoal population in cattle and its relationship to cellulolytic ciliate protozoa. Anim Feed Sci Technol. 1990;29:159-69.

10. Ushida K, Kaneko T, Kojima Y. Effect of presence of large entodiniomorphid protozoa on the rumen bacterial flora, fauna composition of small entodinia and in vitro cellulolysis and xylanolysis.Jpn J Zootech Sci (Japan). 1987;58:893-902.

11. Jouany JP, Demeyer DI, Grain J. Effect of defaunating the rumen. Anim Feed Sci Technol. 1988;21:229-65.

12. Kaneko T, Ushida K, Kojima Y. Effect of starch on cellulolysis by rumen microbial populations with or without protozoa. In: Nolan JV Leng RA, Demeyer DI, editors. The roles of protozoa and fungi in ruminant digestion. Armidale, Australia: Penambul Books; 1989. p. 313-5.

13. Maiga HA, Schingoethe DJ, Henson JE. Ruminal degradation, amino acid composition, and intestinal digestibility of the residual components of five protein supplements. J Dairy Sci. 1996;79:1647-53.

14. Susmel P, Spanghero M, Mills CR, Stefanon B. Rumen fermentation characteristics and digestibility of cattle diets containing different whey:maize ratios. Anim Feed Sci Technol. 1995;53:81-9.

15. Woods W, Burroughs W. Effect of whey and lactose in beef cattle rations.J Dairy Sci. 1962;45:1539-41.

16. Miron J, Ben-Ghedalia D, Yokoyama MT, Lamed R. Some aspects of cellobiose effect on bacterial cell surface structures involved in lucerne cell walls utilization by fresh isolates of rumen bacteria. Anim Feed Sci Technol. 1990;30:107-20.

17. KFSE Council. Korean feeding standard for Korean cattle (Hanwoo). Wanju, Korea: National Livestock Research Institute; 2007. http://www.nias.go.kr. Accessed $20 \mathrm{Feb} 2007$.

18. AOAC. Official methods of analysis. 13th ed. Washington, DC: Association of Official Analytical Chemists; 1980.

19. McCready RM, Guggolz J, Silviera V, Owens HS. Determination of starch and amylose in vegetables. Anal Chem. 1950;22:1156-8.

20. Erwin ES, Macro GJ, Emery EM. Volatile fatty acid analyses of blood and rumen fluid by gas chromatography. J Dairy Sci. 1961;44:1768-71.

21. Lee SB, Choi CW, Jin YC, Wang T, Lee KH, Ku MB, et al. Effect of oral administration of intact casein on gastrointestinal hormone secretion and pancreatic $\alpha$-amylase activity in Korean native steer. Asian-Australas J Anim Sci. 2013;26:65460.

22. Lee KH, Lee JS, Wang T, Oh JJ, Roh S, Lee HG. Role of ghrelin in the pancreatic exocrine secretion via mitogen-activated protein kinase signaling in rats. J Anim Sci Technol. 2017;59:16.

23. Lee KH, Wang T, Jin YC, Lee SB, Oh JJ, Hwang JH, et al. Identification of proteins involved in the pancreatic exocrine by exogenous ghrelin administration in Sprague-Dawley rats. J Anim Sci Technol. 2014;56:6.

24. Roe JH. The determination of sugar in blood and spinal fluid with anthrone reagent.J Biol Chem. 1955;212:335-43.

25. Ludden PA, Wechter TL, Hess BW. Effects of oscillating dietary protein on ruminal fermentation and site and extent of nutrient digestion in sheep.J Anim Sci. 2002;80:3336-46.

26. Ipharraguerre IR, Clark JH, Freeman DE. Varying protein and starch in the diet of dairy cows. I. Effects on ruminal fermentation and intestinal supply of nutrients. J Dairy Sci. 2005;88:2537-55.

27. Purser DM, Buechler SM. Amino acid composition of rumen organisms. J Dairy Sci. 1966;49:81-4.

28. Gorosito AR, Russell JB, Van Soest PJ. Effect of carbon-4 and carbon-5 volatile fatty acids on digestion of plant cell wall in vitro. J Dairy Sci. 1985;68:840-7.

29. Bohnert DW, Larson BT, Bauer ML, Branco AF, McLeod KR, Harmon DL, et al. Nutritional evaluation of poultry by-product meal as a protein source for ruminants: Effects on performance and nutrient flow and disappearance in steers. J Anim Sci. 1998;76:2474-84.

30. Cummins KA, Papas AH. Effect of isocarbon-4 and isocarbon- 5 volatile fatty acids on microbial protein synthesis and dry matter digestibility in vitro. J Dairy Sci. 1985;68:2588-95. 
31. Langlois A, Corring T, Cuber JC, Gueugneau AM, Levenez F, Chayvialle JA. Effects of pancreatic polypeptide on the pancreatic exocrine secretion stimulated by secretin and cholecystokinin in the conscious pig. Regul Pept. 1989;24:55-65.

32. Hara H, Ohyama S, Hira T. Luminal dietary protein, not amino acids, induces pancreatic protease via CCK in pancreaticobiliary-diverted rats. Am J Physiol Gastrointest Liver Physiol. 2000;278:G937-45.

33. Bethard GL, James RE, McGilliard ML. Effect of rumen-un- degradable protein and energy on growth and feed efficiency of growing Holstein heifers.J Dairy Sci. 1997;80:2149-55.

34. Hashimoto N, Hara H. Dietary branched-chain amino acids suppress the expression of pancreatic amylase mRNA in rats. Biosci Biotechnol Biochem. 2004;68:1067-72.

35. Sosa I, Leyton L, Corea E, Elizondo-Salazar J. Correlation between milk and blood urea nitrogen in high and low yielding dairy cows. Rome: Food and Agriculture Organization; 2010. p. 79-82. 